\title{
Migration Corridors: A Study on Murshidabad, West Bengal
}

\section{Urmi Basu}

Department of Economics, Rabindra Bharati University, Emerald Bower Campus, 56A, B.T. Road, Kolkata - 700 050, West Bengal, India

*Corresponding author: urmibasu86@gmail.com (ORCID ID: 0000-0001-6635-7123)

Received: 06-04-2019

Revised: 01-07-2019

Accepted: 25-07-2019

\begin{abstract}
Musrshidabad can well be labelled as one of the most backward districts [Human Development Index (HDI) of Murshidabad is 0.46] in West Bengal. There are a host of factors which have contributed to such a poor reflection of the district's HDI. Absence of any major industries, lack of employment opportunities, rapid growth in number joining the workforce and so many other factors have led to low per capita income of this district, making it literally a seedbed for out-migration of regular and casual labourersskilled/un-skilled/ or low-skilled. People in huge numbers from here have, for the recent last few decades, been migrating not only to different parts of the country but abroad as well. This paper studies the migration from various angles. It has been observed that migrants from here have been using fixed routes connecting the places of origin and the destinations- thus establishing certain migration corridors. Focus has specially been attached to explore categorically these migration corridors and the contacts or intermediaries associated with the operation of these channels perennially. The issue of remittances has been carefully examined. On the whole, this paper investigates different distinctive facets of out-migration from Murshidabad district of West Bengal.

Highlights

( Perceptible Migration Corridors from Murshidabad have been identified.

0 Both international and inter-state migration have been observed as perennially operational in this district.

(0 Out-migrants' migration profile are explored.
\end{abstract}

Keywords: Migration corridors, Murshidabad migrants, Migration to Saudi Arabia, Inter-state migration.

Migration has since long been playing a vital role in shaping the socio-economic condition particularly of rural India. Generally, migration takes place from the economically less developed places to the better ones. In the process the regional economic imbalance, to some extent, is wiped away by the movement of people (Hazra, 2012). The male populace of rural India prefer to out-migrate for employment related reasons (64 ${ }^{\text {th }}$ NSS Round, 2007-08). Rogaly and Rafique (2003) have done an extensive work on Murshidabad migrants engaged in agricultural-wage work and their difficulties to save. Another work on migrant workers from Murshidabad, which is one of the major source districts of migrants working in Kerala, has been done by CMID (Centre for Migration and Inclusive Development) to have an insight into the pattern of migrant labourers in Kerala. It also seeks to explore the sectors they engage themselves and the spread of these workers throughout the state (Peter and Narendran, 2017). There are some other works on Murshidabad, which deal with the causes and consequences of migration (Ali, 2018), determinants, levels of development, impacts of out-migration at the origin and remittances (Kundu, 2012, 2013).

According to West Bengal Human Development Report (2004), the Human Development Index (HDI) of Murshidabad is 0.46 , so the district can well be categorised as one of the backward districts in West Bengal and during the pilot survey on migration in 
a bid to find out the research gaps, it is discovered that there exists certain migration corridors in Murshidabad which have been running for quite a few decades, making it now a perennial passage for both internal and international migration emanating from the remote part of this backward district. From the foregoing it is noticed while only a few number of scholars have examined some aspects of migration here - like agricultural wage, new forms of agency and subjectivity that contemporary forms of mobility are implanted in - little attention has been attached till date to migration corridors. With all these considerations in view, this paper investigates the various factors and reasons behind the working and operation of the migration corridors in this part of the country. This paper also tries to examine the complex and often contradictory nature of migration corridors by exercising both the theoretical and empirical understanding of these corridors to remain operational for such a long period of time with increasingly greater volume. The involuntary migration (due to riots, ethno-religious conflicts etc) has been kept beyond the ambit of this paper. This study has taken into account only the economic factors which are responsible for migration decisions from the district of Murshidabad.

In this context, it is worth mentioning that this paper has focused to explore different migration corridors, both internal and international, quite thoroughly. The volume of migration from Murshidabad is not only very high and regular but casual labourers, who migrate regularly in fixed routes linking the place of origin and the destination, establish migration corridors, as our data corroborate. Both primary and secondary data have been used for the purpose of exploring the profile of out-migration in Murshidabad, Secondary data that have been used here, are Census data (2011), NSS 64th round data (2007-08), West Bengal Human Development Report (2004) and UNDP Human Development Reports (2011, 2015). For the primary data, we have used the stratified sampling technique to carry out our survey. The survey covers all the 5 sub-divisions of Murshidabad District, and 10 villages (two villages from each sub-division). A total sample of 500 respondents are taken. So, the field survey is based on these 500 samples which provide a broad base to explore the ground reality of the migration scenario of Murshidabad.

\section{Migration Corridors}

In this paper, we have considered 'a migration corridor' which has satisfied the following conditionality.

- Migration period is long-term in nature, not less than 6 months and up to 2 to 3 years.

- The distance between the origin and the destination is long enough (say, not less than $1000 \mathrm{~km}$ ), and not feasible to commuting.

- Connectivity between the origin and the destination is hassle-free. In terms of accessibility, it is quite convenient, connected via established road, rail routes/ flights. People migrate frequently making the corridor smoother and acceptably permanent in nature.

- Migration is regular and consistent in nature throughout the corridor. Migrants move to and fro within more or less fixed routes. It has fixed patterns in consonance with the destinations and works.

- Migration networks play an important role within the corridor. Usually the whole migration process is informally organized by apparently invisible intermediaries.

- Migrants are not refugees here; they generally have an ancestral and rural back-up. They mostly migrate in regular intervals to join in works or better works.

- Regular flow of remittances has also been examined.

Our study ferrets out a few corridors. Only top five destinations have been taken out from our study. These are- Kerala (18.80 per cent), Saudi Arabia (17.60 per cent), Gujarat (6.40 per cent), Maharashtra [Mumbai] (5.60 per cent) and Delhi [NCR] (5.20 per cent). There have been quite a high incidence of migration to Kolkata or its vicinity, but it is discarded for being considered as a 'migration corridor' because here most of the migrations are short-term ones, and since the distance between origin and destination being around $200 \mathrm{~km}$, some commuters (weekly) have also been found. Overall, no fixed networks or patterns are observed within this group i.e., it is irregular in nature.

This paper explores the migration corridors from Murshidabad, both cross-border and across subnational borders. The figure (i.e. Fig. 1) show a 
ballpark estimate of migration from Murshidabad, according to the choices of the destinations of the out-migrants.

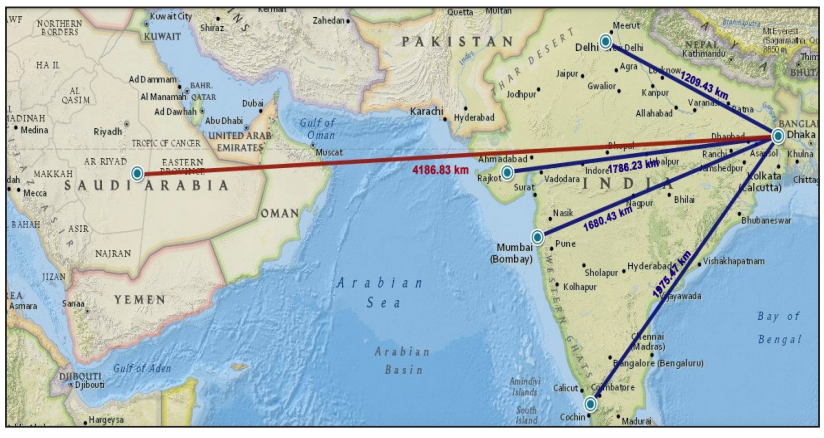

Source: Primary data (prepared by the author using National Geographic Mapmaker)

Fig. 1: An overview of Migration Corridors from Murshidabad

\section{Destinations}

According to NSSO data (64 ${ }^{\text {th }}$ round, 2007-08), nearly 7 per cent of the male out-migrants from the rural areas have taken up residence in another country. The primary data reveal that destination for most of the international migrations from Murshidabad is Saudi Arabia. According to the UNDP, Human Development Report (2011), the total population of Saudi Arabia is 28.1 millions. With such a small population size and abundant Natural Oil Resources, the average income of the citizens is very high.

So, the Saudi nationals are reluctant to do unskilled and lowly manual job themselves. Rather, they go for hiring personnel who would do it for them (Zachariah, Rajan, Joseph, 2016). Due to the dearth of local workers, the emigrants from country like India are made to carry out the jobs of some informal sectors such as cleaning, maintenance, the job of labourers in construction etc. The net migration rate (per 1000 people) in case of Saudi is 2.1 (data are average annual projected for 20102015), whereas for India, it is -0.4 (UNDP, Human Development Report, 2015). It is quite clear from the data that in Saudi in-migration is higher, and while in India, out-migrants far outnumber the in-migrants. From the primary data, it is observed that out of the total migration from Murshidabad to Saudi Arabia, the two cities viz. Riyadh and Jeddah are fed by most of the migrants. The two other destinations are Mecca and Dammam respectively.
Table 1: Distribution of migrants according to destinations - Saudi Arabia

\begin{tabular}{cc}
\hline Saudi Arabia & Migrants \\
\hline Riyadh & 43.18 \\
Jeddah & 34.09 \\
Mecca & 15.91 \\
Dammam & 6.82 \\
\hline Total & $\mathbf{1 0 0}$ \\
\hline
\end{tabular}

Source: Primary data (in percentage).

Kerala itself is a huge source of migrants moving out especially to the Gulf countries. As a huge number from the workforce of Kerala moves out, it creates a void in the local supply of workers (Zachariah, Rajan, Joseph, 2016). Hence, Kerala suffers from perennial labour crisis. Situation becomes worse during the upswing when they urgently require a large number of workers, even at a very high wage. Therefore, higher wages, potential employment opportunities due to under-supply of local workers make Kerala a haven for migrants from other Indian States (Saikia, 2014). As a result, Kerala has been experiencing a huge inrush of migrant labourers from different parts of the country (Surabhi and Kumar, 2007). So far as migration from Murshidabad to Kerala is concerned, we have been able to find out the corridors that exist to different districts in Kerala, viz. Ernakulum, Thrissur, Malappuram, Idukki etc.

Table 2: Distribution of migrants according to destinations - Kerala

\begin{tabular}{cc}
\hline Kerala & Migrants \\
\hline Ernakulam & 55.32 \\
Thrissur & 25.53 \\
Malappuram & 13.83 \\
Idukki & 5.32 \\
\hline Total & $\mathbf{1 0 0}$ \\
\hline
\end{tabular}

Source: Primary data (in percentage).

Gujarat has a large number of migrants from the other States which are mostly absorbed in mega cities of the State. Since the cities are highly industrial, the construction sectors at these places have been a favourite destination for the interstate migrants (Sugandhe, 2017). It is clearly seen that several major industries have developed here. And it is still making progress with a substantial contribution by the migrant workforce. The rapid 
economic growth of Gujarat owes a lot to these workers. In the recent years the construction sector, as a whole, is the fastest growing sector in India. This sector is a big source of employment for the migrant populations in the country (Deshingkar and Akter, 2009). With the development of industrial sector more job opportunities have been created for low/unskilled labourers and the skilled labourers as well. As a sequel, a lot of migrants have been attracted to Gujarat from the other states of the country. This paper draws on research on migration corridor from Murshidabad to Gujarat, especially to the mega cities, like Ahmedabad, Surat and Rajkot.

Table 3: Distribution of migrants according to destinations - Gujarat

\begin{tabular}{cc}
\hline Gujarat & Migrants \\
\hline Ahmedabad & 46.88 \\
Surat & 32.25 \\
Rajkot & 21.88 \\
Total & $\mathbf{1 0 0}$ \\
\hline
\end{tabular}

Source: Primary data (in percentage).

The migration corridor between Murshidabad and Maharashtra can be traced specifically to different places in Mumbai, viz. Worli, Mahalakshmi, Masjid Bandar etc. There is no denying the fact that migration has been a huge factor in the process of economic growth and development of Mumbai. The infrastructural development with ramifications of roads, railways, air links and port has led to the outmigrants being thronged here in droves from every nook and corner of the country. The greater prospect of finding a job acted as a catalyst especially for the poor rural people to crowd into this city. The population of Mumbai has gone up manifold in quick time because of the livelihood opportunities it always has on offer. This rapid growth of population has led to many unauthorised settlements and a swath of slums and shanties in and around the neighbourhood of Mumbai and its conurbations as well (Singh, 2010, Bhagat and Jones, 2014).

In India migration from rural places to thriving economic hubs has been a regular and a common feature for a long time. Mumbai, the so-called financial capital of India, is a big feeder of migrants from all over the country because Mumbai has job for everyone - skilled/ unskilled or low-skilled. With the ever growing informal service sector here the migrants are engaged in menial or minor jobs or at times remain even underemployed (Jha, Kumar, 2016).

Table 4: Distribution of migrants according to destinations - Maharashtra (Mumbai)

\begin{tabular}{cc}
\hline Maharashtra (Mumbai) & Migrants \\
\hline Worli & 46.43 \\
Mahalakhsmi & 39.29 \\
Masjid Bandar & 14.29 \\
\hline Total & $\mathbf{1 0 0}$ \\
\hline
\end{tabular}

Source: Primary data (in percentage).

Though Delhi is still one of the most favourite destinations for the migrants to try their luck for a livelihood or, in some cases, for a higher earning, especially from the Northern neighbouring States as well as from the other parts of the country at large. The development of conurbations of Delhi and the rise of big industrial towns (NCR priority towns) like Gurgaon, Faridabad, Sonipat, Noida, Ghaziabad, Meerut etc. are also contributing to host migrants. In absolute terms, the natural increase of population rise in Delhi in 2017 was estimated to be 2.31 lakh whereas migrants were estimated to be 1.31 lakh. After 1970, the economic growth of Delhi far outclassed the other states in northern India which accelerated the flow of migration to Delhi mushrooming in a huge establishment of the slums and Jhuggi-Jhopri (J.J.) / bastis / clusters (Economic Survey of Delhi, 2018-19). The migration corridor from Murshidabad which we have identified can be observed specifically to NCT Delhi (North, Central and South), Gurgaon and Noida.

Table 5: Distribution of migrants according to destinations - Delhi (NCR)

\begin{tabular}{cc}
\hline Delhi (NCR) & Migrants \\
\hline NCT of Delhi & 19.23 \\
Gurgaon & 34.62 \\
Noida & 46.15 \\
\hline Total & $\mathbf{1 0 0}$ \\
\hline
\end{tabular}

Source: Primary data (in percentage).

\section{Migration Profile}

\section{Religion and Age}

It is noted from the Census data (2011) that in 
Murshidabad, Muslims constitute 66.3 per cent of total population, followed by Hindus (33.2 per cent). Barely 0.5 per cent of the population of the district belong to other religious sections. Naturally the number of Muslim migrants are far more than the Hindu Migrants. But, it is not just this reason responsible for this outcome. Most of the male Muslims learn the masonry work from a very tender age because this artisanship is handed down to them by their ancestors. In the absence of any major industry in this district, Murshidabad offers little scope for employment in infrastructure and construction work. So migrating out is an obvious decision for them. This ancestral artisanship (masonry job) has helped the Muslims migrate out to different parts of the country for sustenance and better source of earning. And they have earned a reputation of being good at it. Also the earlier migrants discovered the different corridors where their skills may be more remunerative and paved the way for subsequent generations to use these corridors. Since these corridors are being used by them almost perennially for a pretty long time, these routes are constantly lubricated by frequent use by them and in its wake they have been able to strike greater contacts and familiarity with the places of destination. Naturally, the present generation finds these corridors to be easily accessible and familiar. In our primary data these corridors have come out conspicuously.

Table 6: Distribution of migrants according to religion

\begin{tabular}{cccccc}
\hline Religion & $\begin{array}{c}\text { Saudi } \\
\text { Arabia }\end{array}$ & Kerala & Gujarat & $\begin{array}{c}\text { Maharashtra } \\
\text { (Mumbai) }\end{array}$ & $\begin{array}{c}\text { Delhi } \\
\text { (NCR) }\end{array}$ \\
\hline Muslim & 94.32 & 80.85 & 96.88 & 82.14 & 69.23 \\
Hindu & 5.68 & 19.15 & 3.13 & 17.86 & 30.77 \\
\hline Total & $\mathbf{1 0 0}$ & $\mathbf{1 0 0}$ & $\mathbf{1 0 0}$ & $\mathbf{1 0 0}$ & $\mathbf{1 0 0}$ \\
\hline
\end{tabular}

Source: Primary data (in percentage).

On the other hand, Hindu population being a minority here, their representation in migration is fewer. But the number of Hindu migrants is also growing rapidly due to poverty and destitution in these rural areas. They are generally using these channels through their Muslim neighbours or other familiar contacts. In the case of International (to Saudi Arabia) migration, the presence of Muslim migrants in huge numbers is quite understandable, as their food habits, religious inclination etc. are almost alike, so it is no wonder that they would be quite comfortable to migrate to this country than their Hindu counterparts. But we observe the same trend in case of internal migration too.

From our study, it is quite clear that the people from the age bracket 16-35 years are more prone to migration than the others. It is unarguably evident that human being remains most agile and productive in the said age bracket. Naturally, any employer would prefer to be benefitted in both ways - cheaper labour cost and larger output. Moreover, at this age a man generally can be very adventurous and has the ability to take a dicey decision and to endure the rigours of travel to a new place and also has the capacity to adapt in the most challenging situations or conditions. So, our data conform to a natural pattern of human behavior and propensity to act thus.

Table 7: Distribution of migrants according to age

\begin{tabular}{cccccc}
\hline $\begin{array}{c}\text { Age } \\
\text { Group }\end{array}$ & $\begin{array}{c}\text { Saudi } \\
\text { Arabia }\end{array}$ & Kerala & Gujarat & $\begin{array}{c}\text { Maharashtra } \\
\text { (Mumbai) }\end{array}$ & $\begin{array}{c}\text { Delhi } \\
\text { (NCR) }\end{array}$ \\
\hline $16-25$ & 29.55 & 19.15 & 21.88 & 32.14 & 42.31 \\
$26-35$ & 36.36 & 27.66 & 31.25 & 42.86 & 34.62 \\
$36-45$ & 22.73 & 19.15 & 18.75 & 21.43 & 11.54 \\
$46-55$ & 11.36 & 25.53 & 21.88 & 3.57 & 11.54 \\
$56-65$ & - & 8.51 & 6.25 & - & - \\
\hline Total & $\mathbf{1 0 0}$ & $\mathbf{1 0 0}$ & $\mathbf{1 0 0}$ & $\mathbf{1 0 0}$ & $\mathbf{1 0 0}$ \\
\hline
\end{tabular}

Source: Primary data (in percentage).

\section{Occupations and Earnings}

The vast majority of Murshidabad emigrants in Saudi Arabia work as masons and manual labourers (89.77 per cent) in the non-agricultural sector. Needless to say that in a country like Saudi Arabia where vegetation is almost non-existent, it is quite obvious that agricultural or farm activities here are microscopic in size. The migrants are mainly engaged in unskilled or semi-skilled activities. Majority of them earn anywhere between ₹ 20000 and ₹ 35000. Other than masonry or as labourers, people are engaged mostly in various menial jobs like cleaning activities, mosque maintenance, jobs in shopping malls, working as a liftman etc.

By sifting our data collected from the source area we have noted that the vast majority of Murshidabad migrants work as manual labourers (65.96 per cent) 
and as masons (24.47 per cent) in Kerala. Other than this, people are engaged in various skilled trades (9.56 per cent), such as mosaic \& tiles artisans, colour \& paint artisans, electricians, carpenters etc. Majority of the migrants earn somewhere between ₹ 8000 and ₹ 26000. Most of these footloose workers do not get themselves rooted to one place or stick to the same work. Minor construction sectors also engage them a lot. Major construction companies and Industries prefer mostly the single male migrant workers, as our data show.

Most migrants from Murshidabad, are working as masons and labourers in the construction sector, which account for 87.50 per cent of total migrants to Gujarat according to our sample. Majority of the migrants earn anywhere between ₹ 13000 and ₹ 25000 per month. Generally, masons get higher wages than the labourers. Most of the migrants get wages on a contractual basis, and often they have to suffer from irregular payments. Other than masons and labourers, we can see people are engaged in different skilled trades like carpentry, repair and maintenance of electrical gadgets, colour \& paint artisanship etc.

Table 8: Distribution of migrants according to occupations

\begin{tabular}{cccccc}
\hline $\begin{array}{c}\text { Occupa- } \\
\text { tions }\end{array}$ & $\begin{array}{c}\text { Saudi } \\
\text { Arabia }\end{array}$ & Kerala Gujarat & $\begin{array}{c}\text { Maharash- } \\
\text { tra (Mum- } \\
\text { bai) }\end{array}$ & $\begin{array}{c}\text { Delhi } \\
\text { (NCR) }\end{array}$ \\
\hline $\begin{array}{c}\text { Labourers' } \\
\text { job }\end{array}$ & 68.18 & 65.96 & 50.00 & 14.29 & 26.92 \\
$\begin{array}{c}\text { Skilled } \\
\text { trade } \\
\text { (Masons) }\end{array}$ & 21.59 & 24.47 & 37.50 & 71.43 & 46.15 \\
$\begin{array}{c}\text { Skilled } \\
\text { trade }\end{array}$ & - & 9.57 & 12.50 & 14.29 & 19.23 \\
$\begin{array}{c}\text { (Others) } \\
\text { Services }\end{array}$ & 10.23 & - & - & - & 7.69 \\
\hline Total & $\mathbf{1 0 0}$ & $\mathbf{1 0 0}$ & $\mathbf{1 0 0}$ & $\mathbf{1 0 0}$ & $\mathbf{1 0 0}$ \\
\hline
\end{tabular}

Source: Primary data (in percentage).

From our primary data, we can observe that in case of Maharashtra (Mumbai), the vast majority of Murshidabad migrants work as masons (71.43 per cent) and labourers (14.29 per cent). Other than masons and labourers, we can see people are engaged in different skilled trades like gold and jewellery workers, or as a mechanic etc.
Generally speaking, people who have acquired some traditional or ancestral skill earn more than their other counterparts. Migrants who are low-skilled or unskilled and have weak contacts, work as ordinary labourers and hence, are poorly paid (Deshingkar, Kumar, Chobey, Kumar, 2006). Majority of the migrants earn anywhere between ₹ 12000 and ₹ 25000 in Maharashtra (Mumbai).

Our primary data, show that a huge number of Murshidabad migrants work as masons (46.15 per cent) in Delhi (NCR). People in the other skilled trades are generally pursuing their careers as, washing machine/AC/refrigerator etc mechanic, embroidery worker, salon worker, security guard, taxi driver, janitor etc. Here majority of the migrants earn anywhere between ₹ 11000 and ₹ 22000. Most of the masons earn more than the labourers. In our study we have found that migrant people (in NCR) who are engaged in skilled trades generally have the same income range as that of the casual labourers.

Table 9: Distribution of migrants according to their earnings (in INR)

\begin{tabular}{cccccc}
\hline $\begin{array}{c}\text { Destina- } \\
\text { tions }\end{array}$ & $\begin{array}{c}\text { Saudi } \\
\text { Arabia }\end{array}$ & & \multicolumn{4}{c}{ Kerala } & Gujarat & $\begin{array}{c}\text { Maharash- } \\
\text { tra (Mum- } \\
\text { bai) }\end{array}$ \\
\hline Earnings & $20000-$ & $8000-$ & $13000-$ & $12000-$ & $11000-$ \\
(monthly) & 35000 & 26000 & 25000 & 25000 & 22000 \\
\hline
\end{tabular}

Source: Primary data.

It is observed from our data that internal migrants generally stay away from their native place for 1012 months. But in case of international migration, it is seen that migrants from Mushidabad, normally enter into an initial contract for a job in Saudi Arabia that run for two to three years. Most of them live in workers' camps (or, in tenements) and in the majority of cases, the number of persons who share a common room, ranges from four to six (sometimes, up to eight) according to the size of the room. Almost all these tenements are permanent (pukka) structures though some are dilapidated. The majority of the Murshidabad migrants (both internal and international) work for 8 to 12 hours a day. Though normally they are supposed to work for 8 hours a day, yet often they are made to work for extra hours without having been paid any extra wages for the overtime job (Mehra and Singh, 2014; Bhogal, 2015). In this way the migrants are 
financially exploited for the reason of oversupply of labourers. Labour-supply are easily regulated with little extra financial burden on the employers as migrants' working hours can be made flexible without any major cost. In regulating the supply of labourers the agents and intermediaries play a vital role in supervising or controlling the recruitment (Sanyal and Maity, 2018). Migrants generally get a day off in a week.

\section{Reasons, Indebtedness, Networks, Remittances}

\section{Reasons}

As said earlier, people migrate from Murshidabad in huge numbers. The primary reason for such a copious out-flow is a dearth of employment opportunities, though at times, in quest for securing a better earning. The major reason for migration from Murshidabad to Saudi Arabia is better earnings, it accounts for 86.36 per cent in our study area. Some migrations occur due to poverty (13.64 per cent) as well. For Kerala, unemployment (63.83 per cent), poverty (31.91 per cent) and higher earnings (4.26 per cent), are the reasons behind the migration decision. Unemployment is the basic reason behind migration to Gujarat.

Table 10: Distribution of migrants according to reasons

\begin{tabular}{cccccc}
\hline Reasons & $\begin{array}{c}\text { Saudi } \\
\text { Arabia }\end{array}$ & Kerala & Gujarat & $\begin{array}{c}\text { Maha- } \\
\text { rashtra } \\
\text { (Mum- } \\
\text { bai) }\end{array}$ & $\begin{array}{c}\text { Delhi } \\
\text { (NCR) }\end{array}$ \\
\hline $\begin{array}{c}\text { Higher } \\
\text { Earnings }\end{array}$ & 86.36 & 4.26 & 6.25 & 39.29 & 19.23 \\
$\begin{array}{c}\text { Poverty } \\
\text { Unem- } \\
\text { ployment }\end{array}$ & 13.64 & 31.91 & 15.63 & 28.57 & 50.00 \\
\hline Total & $\mathbf{1 0 0}$ & $\mathbf{1 0 0}$ & $\mathbf{1 0 0}$ & $\mathbf{1 0 0}$ & $\mathbf{1 0 0}$ \\
\hline
\end{tabular}

Source: Primary data (in percentage).

According to our onsite data, out of the migrants to Gujarat, lack of job opportunities in the places of origin accounts for 78.13 per cent of migration decision. Our primary data also support that poverty is the key factor to push them out of their hearth and home for better earnings. Poverty and higher earnings together are responsible for 21.88 per cent of migration from our study area. For
Maharashtra (Mumbai), higher earnings (39.29 per cent), unemployment (32.14 per cent) and poverty (28.57 per cent) are the reasons behind the migration decision of the migrants. Poverty-driven migration accounts for around 50 per cent of total migration to Delhi (NCR). Among the other reasons, unemployment is responsible for 30.77 per cent of migration, and higher earning is the reason for 19.23 per cent of migration in our survey areas to Delhi (NCR).

\section{Indebtedness}

The migrants dealt with above, generally do not get the opportunity to have an access to a 'formal loan' to meet the initial expenses for travelling, boarding and lodging for the period they move out of their homes till they get some job and its payment. So, they are forced to borrow money to meet the initially unavoidable expenses from their near and dear ones or from people who trust them as a loanee. Situations become even worse when they borrow from the money-lenders who normally extort a very high rate of interest. The amount of indebtedness is higher in case of international migration than that of the inter-state ones, because initially, they have to pay more money to finance their migration abroad. For example, the expenses to migrate from Murshidabad to Saudi Arabia is undoubtedly expensive and initially, the willing out-migrants have to shell out an amount that ranges from $₹ 80,000$ to $₹ 1,00,000$, accordant with the period in transit and the place they propose to migrate. Therefore, indebtedness for the purpose of migration is naturally high in these cases.

Table 11: Distribution of migrants according to indebtedness (in INR)

\begin{tabular}{cccccc}
\hline $\begin{array}{c}\text { Desti- } \\
\text { nations }\end{array}$ & $\begin{array}{c}\text { Saudi } \\
\text { Arabia }\end{array}$ & Kerala & Gujarat & $\begin{array}{c}\text { Maha- } \\
\text { rashtra } \\
\text { (Mumbai) }\end{array}$ & $\begin{array}{c}\text { Delhi } \\
\text { (NCR) }\end{array}$ \\
\hline Debts & $30000-$ & $7000-$ & $12000-$ & $7500-25000$ & $13000-$ \\
& 150000 & 25000 & 30000 & & 25000 \\
\hline
\end{tabular}

Source: Primary data.

\section{Networks}

It is observed that migration to a specific region largely depends on contacts and networking operational in that particular area. When a particular 
agent or contractor operates in a certain area many willing migrants around that area would migrate with him. Also, if a few migrant workers migrate to a particular city from a particular village because of the existence of certain contacts, their co-villagers would be interested to follow suit. So, the new migrants find it assuring to migrate out accompanying some familiar contacts (Hirway, Singh, Sharma, 2014). In case of Saudi Arabia, most of the people have migrated out with the help of contractors/agents, for sure, through the established migration corridors, as we have discovered. It is also true for internal ones as well. The people who have migrated out with contractors/agents, generally move out in a group. Usually, the migrants do not have to suffer from a long wait to join in work, when they migrate through the intermediaries, and if they have to wait at all, the period hovers around 5 to 15 days. In most of the cases in our primary data we have found that, the travel expenses, meal expenses and staying expenses are borne by the migrants themselves. Only in a few cases, contractors have made the payments. Other than contractors, migration also takes place through relatives/friends who happen to be their families or co-villagers. For Kerala, Gujarat and Delhi (NCR), only in a few cases, we have noticed that the migrants migrated out by themselves, and they are mostly engaged in skilled trades.

Table 12: Distribution of migration carried out self/ via intermediaries

\begin{tabular}{|c|c|c|c|c|c|}
\hline $\begin{array}{l}\text { Migrating } \\
\text { with }\end{array}$ & $\begin{array}{l}\text { Saudi } \\
\text { Arabia }\end{array}$ & Kerala & Gujarat & $\begin{array}{c}\text { Maha- } \\
\text { rashtra } \\
\text { (Mum- } \\
\text { bai) }\end{array}$ & $\begin{array}{l}\text { Delhi } \\
\text { (NCR) }\end{array}$ \\
\hline $\begin{array}{l}\text { Con- } \\
\text { tractors/ } \\
\text { Agents }\end{array}$ & 85.23 & 48.94 & 59.38 & 78.57 & 53.85 \\
\hline $\begin{array}{c}\text { Relatives/ } \\
\text { Friends }\end{array}$ & 14.77 & 39.36 & 34.38 & 21.43 & 30.77 \\
\hline Self & - & 11.70 & 6.25 & - & 15.38 \\
\hline Total & 100 & 100 & 100 & 100 & 100 \\
\hline
\end{tabular}

Source: Primary data (in percentage).

\section{Remittances}

Every day, on an average, more than one thousand migrant workers are emigrated from India to find a job in Saudi Arabia. They remit approximately
500 billion INR per annum back to India (Amnesty International, 2014). In our study too, it is perceived that a significant proportion of out-migrants have sent remittances to their respective households in the areas of origin. From our data from Saudi Arabia, it is evident that most of the remittances come from the masons and labourers, because their contributions to the migrant-workforce are the highest. In our survey, for inter-state migration, too, it is seen that a significant proportion of out-migrants have sent remittances to their respective households in the areas of origin. But, naturally, the amount of remittances are higher for the international migrants than their national counterparts. Migrants generally send remittances 4 to 5 times a year.

Table 13: Distribution of migrants according to remittances (in INR)

\begin{tabular}{cccccc}
\hline $\begin{array}{c}\text { Destina- } \\
\text { tions }\end{array}$ & $\begin{array}{c}\text { Saudi } \\
\text { Arabia }\end{array}$ & Kerala & Gujarat & $\begin{array}{c}\text { Maha- } \\
\text { rashtra } \\
\text { (Mumbai) }\end{array}$ & $\begin{array}{c}\text { Delhi } \\
\text { (NCR) }\end{array}$ \\
\hline $\begin{array}{c}\text { Remit- } \\
\text { tances }\end{array}$ & $10000-$ & $3000-$ & $5000-$ & $6000-$ & $5000-$ \\
\hline
\end{tabular}

Source: Primary data.

In our findings, majority of the migrants' families utilize the remittances on basic consumption purposes, in a few cases it is used for the purpose of buying livestock, repairing and maintenance of dwelling places and bettering them. In a still fewer cases, some families have acquired leasehold property or landed property out of the remitted funds. The low or un-skilled migrants, in some cases, acquire some skills during the period of their working at the places of destination. They bring back with them job knowledge, a variety of working skills, innovative ideas etc. known as social remittances which contribute greatly for economic development at the areas of origin.

\section{CONCLUSION}

This study unfolds the distinctive aspects of outmigration from Murshidabad district of West Bengal. During the course of our study we have examined the different reasons for migration and the distinguishing factors that lead to taking migration decisions. We have paid our pointed attention to the rationale for selection of particular places as destination by the migrants as well. Our study reveals that migration from Murshidabad 
takes place not only in droves, but it also uncovers a fact that a huge number of regular and casual labourers migrate regularly in fixed routes linking the place of origin and the places of destination - thus establishing a migration corridor. We have attempted to explore the migration corridors from the angle of both intra-border and cross-border scenarios. Our findings disclose that for the migrants from Murshidabad the destinations are mainly- Saudi Arabia, Kerala, Gujarat, Maharashtra and Delhi (NCR).

Here we must mention one thing, which corroborates our study, is that the migrants often become a victim of indifference. As they have to live temporarily both at the place of origin and at the place of migration destination as a shuttle cork, they often fall between two stools. Neither the local administration at origin nor at destination takes proper care of them. Though some works on migration have pointed out a few anomalies on flagrant deprivation of the migrants, along with a few recommendations on their ease of communication and stay, at least within the country, and also for redressal of some core issues for the amelioration of migrants' conditions on the whole, but still a lot to be achieved on this score. We have miles to go to address it.

\section{ACKNOWLEDGEMENTS}

This treatise on 'Migration Corridors' constitutes a part of the author's doctoral thesis, which is underway at the Department of Economics, RBU, Kolkata. The author would like to thank the UGC, Government of India for awarding the SRF (Senior Research Fellowship) under 'Swami Vivekananda Single Girl Child Fellowship' for research in Social Sciences. The author owes a special thanks to Dr. Swati Ghosh, professor in the department of Economics at RBU, for her guidance in the arduous course of research work through meaningful discussions. Her discourses have proved to be of immense help to the author.

\section{REFERENCES}

Ali, M. D. Hasan. 2018. Causes and Consequences of Outmigration: A Study in Murshidabad District, West Bengal, India. International Journal of Development Research, 08(1): 18189-18194.

Amnesty International, 2014. Exploited Dreams: Dispatches from Indian Migrant Workers in Saudi Arabia. India, Bangalore.
Bhagat, R.B. and Gavin, W. Jones. 2014. Demographic Dynamics of Mega-Urban Regions: The Case of Mumbai. Demography India, 43(1\&2): 71-94.

Bhogal, S. 2015. Migrant Labour and Industrial Work Environment: A Relationship Vital to National development. Economic Affairs, 60(2): 291-299.

Census of India. 2011. District Census Handbook Murshidabad. Directorate of Census Operations, West Bengal.

Deshingkar, P. and Akter, S. 2009. Migration and Human Development in India. United Nations Development Programme (UNDP).

Deshingkar, P., Kumar, S., Chobey, H. K. and Kumar, D. 2006. The Role of Migration and Remittances in Promoting Livelihoods in Bihar. Overseas Development Institute, London.

Government of NCT of Delhi. 2019. Economic Survey of Delhi. 2018-19. Planning Department, New Delhi.

Government of West Bengal. 2004. West Bengal Human Development Report. Development and Planning Department, West Bengal.

Hazra, A. 2012. Rural India: Still Floating Towards Cities. Kurukshetra, 60(4): 3-5.

Hirway, I., Singh, U.B. and Sharma, R. 2014. Migration and Development Study of Rural to Urban Temporary Migration to Gujarat. Centre for Development Alternatives, Ahmedabad.

Human Development Report. 2011. Sustainability and Equity: A Better Future for All. United Nations Development Programme (UNDP).

Human Development Report. 2015. Work for Human Development. United Nations Development Programme (UNDP).

Jha, M.K., Kumar, P. 2016. Homeless Migrants in Mumbai: Life and Labour in Urban Space. Economic and Political Weekly, 51 (26-27): 69-77.

Kundu, S.K. 2012. Impact of Rural Labour Out-migration on Availability of Labour-force at Source area: An Opinion Survey in the block of Dumkal in Murshidabad district, West Bengal. International Journal of Social Science, 1(2): 203-209.

Kundu, S.K. and Mondal, D. 2012. Levels of Development in Murshidabad District of West Bengal: A Block Level Study. Journal of Landscape Systems and Ecological Studies, 35(1): 515-522.

Kundu, S.K. 2013. Determinants of Rural Labour OutMigration: An Experience from Dumkal Block of Murshidabad District, West Bengal. Asian Journal of Research in Social Sciences and Humanities, 3(2): 67-70.

Kundu, S.K. 2013. Impact of Labour out-migration and Remittance on Rural areas: A Case study from West Bengal, India. Research Journal Humanities and Social Sciences, 4(2): 190-195.

Mehra, S. and Singh, G. 2014. Implications of Migration: A Case Study of Industrial Migrant Labourers in Ludhiana. Economic Affairs, 59(2): 117-127. 
NSSO 2010. Migration in India. 2007-2008. NSS $64^{\text {th }}$ Round, Report No. 533, National Sample Survey Office, Ministry of Statistics \& Programme Implementation, Government of India.

Peter, B. and Narendran, V. 2017. God's Own Workforce: Unravelling Labour Migration to Kerala. Centre for Migration and Inclusive Development, Kerala.

Rogaly, B. and Rafique, A. 2003. Struggling to Save Cash: Seasonal Migration and Vulnerability in West Bengal, India. Development and Change, 34(4): 659-681.

Saikia, D. 2014. Economic conditions of the migrant workers in Kerala: A Study in the Trivandrum district. Journal of Indian Research, 2(4): 33-46.

Sanyal, T. and Maity, K. 2018. On Labour Migration in India: Trends, Causes and Impacts. Economic Affairs, 63(1): 57-69.
Singh, D. P. 2010. Employment Situation in Mumbai: An Analysis. http://2fwww.global-labour-university. org/fileadmin/GLU_conference_2010/papers/44._ Employment_situation_in_Mumbai_An_analysis.pdf

Sugandhe, A.S. 2017. Gujarat Becoming New Destination for Inter-State Migrants. Journal of Economic \& Social Development, XIII (1).

Surabhi, K.S. and Kumar, N.A. 2007. Labour Migration to Kerala: A Study of Tamil Migrant Labourers in Kochi. Working Paper No.16, Centre for Socio-economic \& Environmental Studies (CSES), Kerala.

Zachariah, K.C., Rajan, S.I. and Joseph, J. 2016. Kerala Emigration to Saudi Arabia, prospects under the Nitaqat law. In: Rajan S.I. (ed) India Migrations Reader, South Asia edn. Routledge, London and New York. 